胃癌所属リンパ節の抗腫瘍的な免疫応答について

\begin{tabular}{|c|c|c|c|c|c|}
\hline \multicolumn{6}{|c|}{ 東京女子医科大学第 2 病院外科 } \\
\hline 小川 & 健治 & 矢川 & 裕一 & 勝部 & 隆男 \\
\hline 川田 & 裕一 & 大谷 & 洋一 & 榊原 & 宣 \\
\hline
\end{tabular}

\title{
A STUDY ON ANTI-TUMOR REACTION OF REGIONAL LYMPH NODES IN GASTRIC CANCER
}

\author{
Kenji OGAWA, Hirokazu YAGAWA, Takao KATSUBE, \\ Hirokazu KAWATA, Yoichi OHTANI and Noburu SAKAKIBARA \\ Department of Surgery Tokyo Women's Medical College Daini Hospital
}

索引用語：胃癌所属リンバ節，免疫応答，OK-432

はじめに

腫汮所属リンパ節は抗腫瘍性免疫反応の発現および 維持の場であると認識され(1) 3), 生体の腫煌に対する 防御の最前線をなすといわれている. 所属りンパ節に は具体的にどういった免度応答がおこり，そのリンパ 節はどのような機能をるち，どのような役割を果たす のであろらか.ささらに外科臨床の場に䗋いて，その郭 清はどう考学ればよいのであろらか。これら諸点に関 して，実験的およびヒト胃癌で臨床的に検討したので 報告したい。

\section{検索方法およひ結果}

1. 実験的にみた所属リンパ節の免疫応答

$\mathrm{C} 3 \mathrm{H} / \mathrm{He}$ マゥスの右足蹠皮下に同系の腹水肝癌 MH134を移植し以下の検索を行った。

まず，移植 7 日前に右鼡径および㮏窝リンパ節（所 属リンパ節）と左の同じリンパ節（遠隔リンパ節）を 摘出したマウス, 対照の無処置マウスにMH134を移 植し, 所属リンパ節の有無が腫湟增殖にどのよ5に影 響するかみた。所属リンパ節摘出群の腫瘍径は遠隔リ ンパ節摘出群や無処置対照群に比べて移植後早期より 大きく, 25日目まで有意に増大した $(\mathrm{p}<0.05)$ (図 1 ).

つぎに, 腫場を移植して $1,3 ， 6 ， 10 ， 15 ， 20$ 日目に 各リンパ節を無菌的に摘出, リンパ球を分離して

\footnotetext{
※第26回日消外総会シンポ II：消化器癌リンパ節応答 とその郭清

$<1985$ 年11月 12 日受理 >別刷請求先：小川 健治 T116 荒川区西尾久 2-1-10 東京女子医科大学 第 2 病院外科
}

図 1 リンパ節摘出担癌マウスの尰瘍増殖曲線

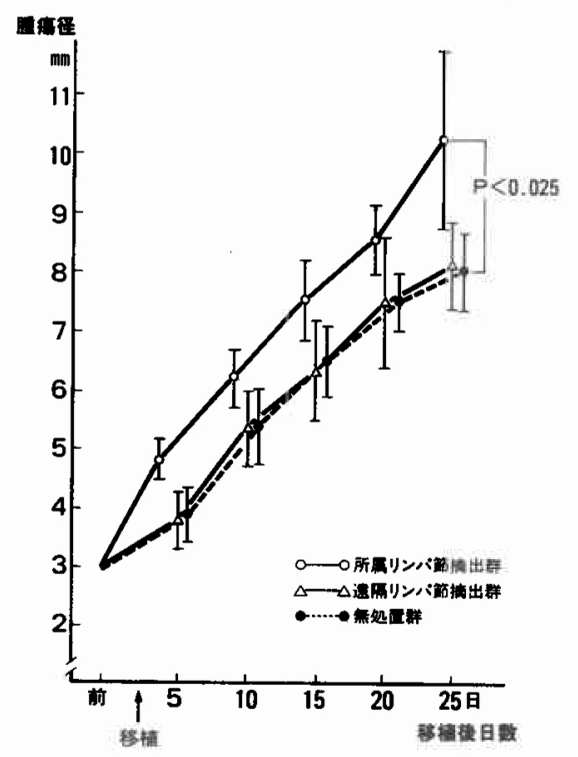

Thy1・2抗原陽性細胞比, PHA 幼若化反応を測定, さ らに Winn の中和試験を行った. Thy1・2抗原陽性細胞 比の推移は，所属リンパ節で 1 日86.5\%，3 日83.9\% （対照の正常マウス $80.8 \%$ )と上昇がみられたが，6日 では72.7\%となり以後は経過とともに低下した。遠隔 リンパ節では 1 日83.0\%，3 日80.1\%，その後は軽度 に低下するが大きい变動はなかった．PHA 幼若化反 応のSI 值の推移は, 所属リンパ節で 1 日27.1，3 日 24.5 (対照20.2) とやはり上昇をみたが，6 日では 18.0 
表 1 Thy $1 \cdot 2$ 抗原陽性細胞比の推移

\begin{tabular}{|c|c|c|c|c|c|c|c|}
\hline & 腫瘍移植後 & 7 日 & 9 日 & 12日 & 16日 & 21日 & 26日 \\
\hline \multirow{2}{*}{ 所属リンパ節 } & OK-432投与群 & $55.6 \%$ & 45.9 & 41.7 & 35.1 & 29.5 & 22.6 \\
\hline & 生食水投与群 & $36.3 \%$ & 37.0 & 32.8 & 27.3 & 26.8 & 18.4 \\
\hline \multirow{2}{*}{ 遠隔リンパ節 } & OK-432投与群 & $54.2 \%$ & 54.9 & 59.6 & 63.6 & 66.4 & 63.5 \\
\hline & 生食水投与群 & $50.0 \%$ & 49.2 & 51.7 & 56.1 & 66.3 & 55.1 \\
\hline
\end{tabular}

表 2 PHA幼若化反応のSI值の推移

\begin{tabular}{|c|c|c|c|c|c|c|c|}
\hline & 腫瘍移植後 & 7 日 & 9 日 & 12日 & 16日 & 21日 & 26日 \\
\hline \multirow{2}{*}{ 所属リンパ節 } & OK-432投与群 & 86.1 & 82.7 & 16.8 & 3.0 & 1.6 & 1.7 \\
\hline & 生食水投与群 & 50.6 & 46.9 & 7.6 & 1.8 & 1.3 & 1.2 \\
\hline \multirow{2}{*}{ 遠隔リンバ節 } & OK-432投与群 & 65.4 & 62.6 & 57.7 & 42.5 & 48.0 & 45.6 \\
\hline & 生食水投与群 & 54.7 & 53.4 & 50.4 & 41.1 & 38.0 & 37.1 \\
\hline
\end{tabular}

となり以後は急激に低下した。遠隔リンパ節では 1 日 $21.7,3$ 日21.5, その後も大きい変動はなかった。中 和試験でみた特異的な抗腫瘍性の推移は, 所属リンパ 節で担癌いずれの時期にも抗腫瘍性が認められ，とく に担癌初期の 1 日，3 日では有意差を認めた $(\mathrm{p}<$ 0.01). 遠隔リンパ節では担癌中期以降の20日で抗腫痬 性が発現した（p<0.05）。

さらに，同じ実験系に溶連菌製剂 OK-432を投与し， その所属リンパ節の免度応答に与える影響について以 下の検索を行った.

腫湯を移植して 2，4，6 日目にOK-432を右大駺皮 下に $5 \mathrm{KE}$ ずつ投与した群, 対照として生食水を投与し た群について，7，9，12，16，21，26日目に各リンパ 節を無菌的に摘出，リンパ球を分離してThy1・2抗原 陽性細胞比, PHA 幼若化反応, NK 細胞活性, ${ }^{51} \mathrm{Cr}$ release testによる細胞障害活性を測定した. Thy1・ 2抗原陽性細胞比の推移は, 所属リンパ節で経日的に低 下したが，担癌中期の $7 〜 12$ 日に拈いては，OK-432投 与群の低下は生食水投与群に比べて小さかった。遠隔 リンパ節では逆に経日的に上昇した（表 1 ）。PHA 幼 若化反応の SI 值の推移は, 所属リンパ節で 9 日まで高 值を保ち, 以後は急激に低下したが, 全経過とも OK432投与群は生食水投与群に比べて高値を示した。遠隔 リンパ節では経日的にゆるやかに低下した（表 2).

NK 細胞活性の推移は, 所属りン八節で経日的に低下 したが, OK-432投与群は生食水投与群に比べて高値を 示した。遠隔リンパ節もこれと同じ傾向で変化した(表 3). 細胞障害活性の推移は, 所属リンパ節で経日的に
表 3 NK 細胞活性の推移

\begin{tabular}{|c|c|c|c|c|}
\hline & 腫瘍移植後 & 7 日 & 9 日 & 12日 \\
\hline \multirow{2}{*}{ 所属リンパ節 } & OK-432投与群 & $9.8 \%$ & 4.4 & 2.1 \\
\hline & 生食水投与群 & $5.7 \%$ & 1.5 & 0.7 \\
\hline \multirow{2}{*}{ 遠隔リンパ節 } & OK-432投与群 & $8.4 \%$ & 4.2 & 2.3 \\
\hline & 生食水投与群 & $6.1 \%$ & 2.8 & 1.1 \\
\hline
\end{tabular}

表 4 細胞障害活性の推移

\begin{tabular}{|c|c|c|c|c|}
\hline & 腫畼移植後 & 7 日 & 9 日 & 12 日 \\
\hline \multirow{2}{*}{ 所属リソパ節 } & OK- 432 投与群 & $17.8 \%$ & 11.0 & 2.2 \\
\hline & 生食水投与群 & $6.6 \%$ & 4.0 & 0.9 \\
\hline \multirow{2}{*}{ 遠隔リンパ節 } & OK- 432 投与群 & $6.1 \%$ & 8.6 & 4.4 \\
\hline & 生食水投与群 & $2.9 \%$ & 3.3 & 2.2 \\
\hline
\end{tabular}

低下したが, OK-432投与群は生食水投与群に比べて高 値を示した。 遠隔リンパ節ではあまり変化しなかった (表 4 ).

\section{2. ヒト胃癌所属リンパ節の免疫応答}

胃癌31例（早期15例, 進行16例）を対象に, その術 中に肉眼的に転移陰性と判断された胃癌取扱い規約4) にいら第 1 群リンパ節と第 3 群リンパ節を無菌的に採 取, リンパ球を分離してモノクローナル抗体 $\mathrm{OK} シ$ リーズでみたリンパ球 subsets, PHA 幼若化反応, NK 細胞活性を検索した。

T cell subsets のうち OKT3陽性細胞比（OKT3比） を示せぱ, 第 1 群りンパ節 $51.8 \%$, 第 3 群リンパ節 
図 2 早期胃癌所属リンパ節リンパ球の $\mathrm{T}$ cell subsets
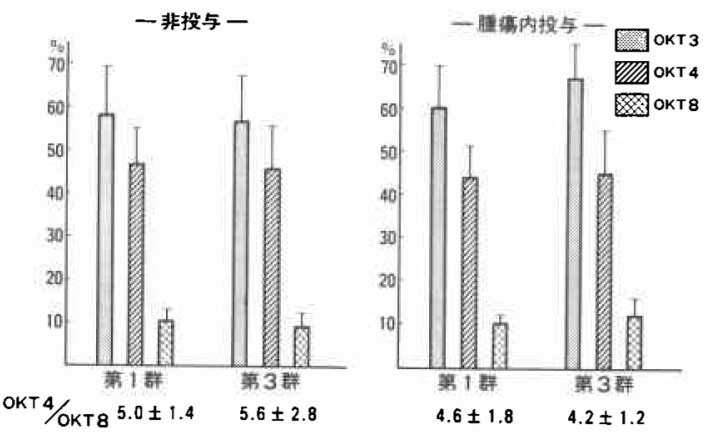

図 3 早期胃癌所属リンパ節リンパ球の PHA 幼若化 反応
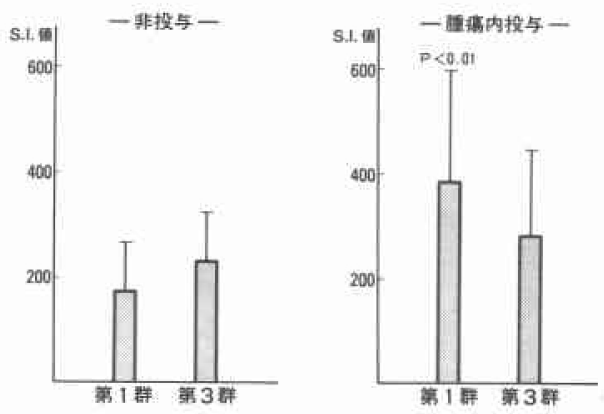

図 4 早期胃癌所属リンパ節リンパ球の NK 細胞活 珄
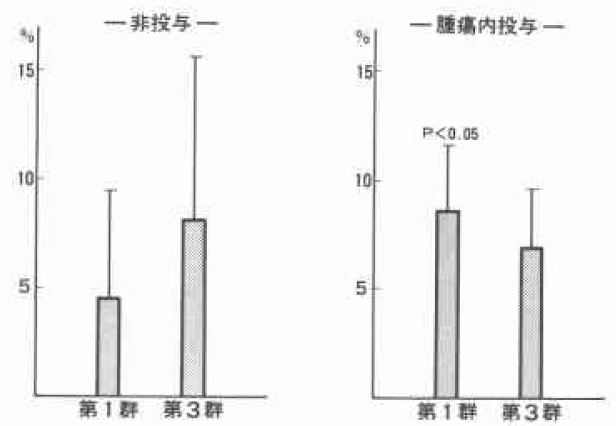

$55.8 \%$ 第 1 群でわずかに低下をみた. PHA 幼若化 反応の SI 値は, 第 1 群リンパ節 175 , 第 3 群リンパ節 196 と第 1 群で低下をみた. NK 細胞活性は, 第 1 群リ ンパ節 $5.0 \%$, 第 3 群リンパ節 $9.0 \%$ と第 1 群で有意の 低下をみた $(p<0.05)$.

つぎに, 早期胃癌 8 例を対象に, 術前 OK-432を経内 視鏡的に腫瘍内および腫瘍周囲粘膜内に $10 \mathrm{KE}$ 投与
し，その所属リンパ節の免疫応答に与学る影響につい て検索した。 OK-432非投与の早期胃癌10例を対照と し，前項と同じパラメーターを湘定した。

T cell subsets は，OK-432腫瘍内投与により第 3 群 の OKT3比がやや上昇したが，それ以外は大きな差を みなかった（図 2）, PHA 幼若化反応の SI 值は，OK. 432 腫㾴内投与により第 1 群, 第 3 群ともに上昇し, と くに第 1 群では有意差を認めた $(\mathrm{p}<0.01)$ (図 3 ). NK 紐胞活性は, OK-432腫瘍内投与により第 1 群では有意 の上秝（p<0.05）をみたが，第 3 群では差を認めな かった（図4).

\section{考察}

近年, 腫瘍免疫学の進歩に伴って, 腫瘍所属リンパ 節の機能や意義が明らかにされてきた。すなわち，抗 腫瘍性免疫反応の発現和よび維持の場であると認識さ れ ${ }^{1) ~ 3)}$, 腫瘍の増殖や進展に抵抗する biological barrierであるといわれている.そこで, その具体的な免疫 応答について，実験的，臨床的に検討してみた。

まず，動物実験で所属リンパ節の抗腫場珄をみた。 所属りンパ節摘出群に移植した腫瘍は，遠隔リンパ節 摘出群や無処置対照群のそれに比較して明らかに大き く増殖した，咲田ら ${ }^{5}$ 子指摘するごとく, 所属リンパ節 に抗腫痬性が示唆された成績と思われる。

さらに,これらのリンパ節にどのよらな免疫応答が 起っているかみるため, 腫瘍移植後のリンパ節のリン パ球動態を経日的に観察した。所属リンパ節では Thy1・2抗原陽性細胞比, PHA 幼若化反応の SI 値之 も移植後 $1 ， 3$ 日で上昇をみたが，小さい転移が形成さ れはじめる 6 日以降では低下した。この担癌初期の上 昇は, 所属リンパ節に流入してくる腫瘍細胞に対し, ヒトの T cell にあたる Thy1・2抗原陽性細胞が増加 し,さらにそれが活性化されたための反応と考えられ， 抗腫瘍性との関連がうかがわれた。中和試験でもとく に $1 ， 3$ 日に抗腫瘍性がみられて拈り,これを裏付ける 成績のように思われる。一方，遠隔リンパ節では， Thy1・2抗原陽性細胞比や PHA 幼若化反応の SI 值に 大きい変動はなかったが，中和試験では，所属りンパ 節の抗腫瘍性が低下した時期にはじめて抗腫瘍性が出 現した。.これらの実験成績から，所属リンパ節には免 疫応答に裏付けられた抗腫瘍性が認められ，その発現 や強さは腫瘍移植後の日数, すなわち睡瘍の進行程度 によることが判明した。ささらに，所属リンパ節のこの 抗腫瘍性は腫痬の進行や転移形成に伴ない低下し，遠 隔リンパ節に移行し，腫場とリンパ節との距離にも関 
係するよらに思われる。

つづいて，同じ実験系に溶連菌製剂 OK-432を投与 し，この所属リンパ節の担癌初期にみられる抗腫瘍的 な免疫応答に与える影響をみた。所属リンパ節では, Thy1 - 2抗原陽性細胞比, PHA 幼若化反応の SI 值々 る腫瘍の進行や転移形成に伴ない低下したが, OK-432 投与群ではこの低下は抑克られた。竹中6) 同じ実験 動物之腫瘍を用いた実験で, OK-432投与後の所属りン パ節の反応はT細胞が主体をなすと同じょうな成績を 報告している。OK-432の投与により，所属リンパ節で は Thy1・2抗原陽珄細胞がまず増加し，さらにその機 能も六進したるのと思われる。一方，遠隔リンパ節で は，OK-432投与の影響ははっきりと認められなかっ た。ささらに，このような所属リンパ節の反応が抗腫瘍 性に結びついているかをみるため，リンパ節リンパ球 の NK 細胞活性, 同系腫㑥である MH134細胞を標的 細胞とした細胞障害活性についてみた。所属リンパ節 では，両者ともやはり経日的に低下したが，OK-432投 与群ではこの低下は抑えられた。押味らうはマウス腹 腔内に OK-432を投与する実験で，OK-432は NK 細胞 活性を賦活することが考えられるとし，また，清水ら はやはりマウスで, OK-432投与によりリンパ節リンパ 球に抗腫瘍活性を誘導できたと報告している。これら を加味して考えると, 所属リンパ節の両活性はかなら ずしす高くなかったが, OK-432投与によりその増強が みられて扣り，このことが抗腫瘍性の発現につながっ ているように思われる。一方, 遠隔リンパ節では, OK. 432投与の影響ははっきりと認められなかった。これら の実験成績から，所属リンパ節の免疫応答は遠隔リン パ節に比べ OK-432投与の影響を強くうけて六進する ことが判明した。 OK-432の投与により，所属リンパ節 の抗腫瘍性を担癌初期から中期にかけて増強させらる よ5に思われる。

ついで, 臨床的にヒト胃癌で所属リンバ節の免疫応 答をみた。すべての T cell に対応する OKT3比, PHA 幼若化反応の SI 値, NK 細胞活性とも, 第 3 群リンパ 節では保たれているが，第 1 群リンパ節では低下を認 めた，著者はすでに，胃癌所属リンパ節の細胞性免疫 能を T細胞比, PHA 幼若化率をパラメーターとして 検索し, 第 1 群, 第 2 群リンパ節では第 3 群リンパ節 に比べ転移の有無にかかわらず低下していること，そ してこの傾向は癌畽が進行したものほど明らかである ことを報告している9．これと一致した成績と考兄ら れ，ヒト胃癌でも，一般に腫瘍に近いリンパ節では細
胞性免疫能は低下して抗腫場性は失われているが，属 瘍から少し離れたリンパ節では，これらは比較的保た れているよ5に思われる.リンパ節転移は, このよう に免疫応答が低下し，抗腫場性が失われたのち形成さ れると考克られら。

そこで，さきの実験成績を考虑し，この低下した第 1 群リンパ節の免疫応答を OK-432の投与で増強でき ないかと考兄，低下の少ない早期胃癌症例を対象に検 討してみた，畽瘍内投与群の所属リンパ節の免疫応答 を非投与群のそれと比較すると，T cell subsetsでは 大きな差はなかったが, PHA 幼若化反応の SI 值, NK 細胞活性はともに，とくに第 1 群リンパ節で有意の上 昇を認めた。 OK-432腫瘍内投与が胃癌所属リンパ節の 免疫応答に与える影響を三輪ら ${ }^{10)}$, 山根ら ${ }^{11)}$ は病理組 織学的なリンパ節反応形態から検索し, 各 lymphoid reaction の克進, lymphocyte predominance がみられ たとのべている，ともに T cell 活性を表現する形態で あり，パラメーターは異なるがこれらに一致する成績 と考えられよ5.OK-432の術前腫崵内投与により，ヒ 卜胃癌でも動物実験と同じように, 所属リンパ節の免 疫応答を増強させうると思われる。早期胃癌の術前に OK-432腫瑒内投与を行えば，郭清にもれたリンパ節に はむしろ抗腫瘍性が期待できるとも考えられ, 現在, 検索を進めている.

\section{おわりに}

担癌動物, ヒト胃癌の腫瘍所属リンパ節には抗看瘍 的な免疫応答が発現しており,さらにそれは, 溶連菌 製剂 OK-432の腫瘍内投与で増強させらることが判明 した．今後はこのような腫煬所属リンパ節の免疫応答 を, 外科臨床の場で応用していくことが課題であると 考えている.

\section{文 献}

1) Fisher B, Fisher ER: Studies concerning the regional lymph nodes in cancer. I. Initiation of immunity. Cancer 27 : 1001-1004, 1971

2) Fisher B, Fisher ER: Studies concerning the regional lymph nodes in cancer. II. Maintenance of immunity. Cancer $29: 1496-1501,1972$

3）中田一也：担癌マウスに和ける所属リン八節の抗 腫場性に関する実験的研究. 東京女医大誌 53 ： $260-272,1983$

4）胃癌研究会編：外科・病理胃癌取扱い規約. 東京, 金原出版, 1979

5）咲田雅一：所属リンパ節の抗腫瑒性についての実 験的研究一外科的操作と所属リンバ節内癌細胞の 動態. 京都府医大誌 $86: 37-49,1977$ 
6）竹中 温: 術前腫㾀内 immunopotentiator 投与 のリンパ節転移抑制効果とリンパ節内細胞反応に ついての実験的研究. 京都府医大誌 89 : $351-364,1981$

7) 押味和夫, 隅谷護人, 権田信広ほか：溶連菌製剂 OK-432 の Natural killer 細胞活性増強作用. 臨免 疫 $11: 867-870,1979$

8）清水史郎, 紺田 進, 小中義照: OK-432 処理×千 ルコラントレン誘発腫瘍マウス各種リンバ組織細 胞の殺腫癔細胞能。日癌会第38回総会記録, 100 ,
1979

9）小川健治：胃癌所属リンパ節の機能的, 形態学的 抗腫煌性に咸する研究。日臨外医会誌 42 ： $101-113,1981$

10）三輪恕昭, 合地 明, 松三 彰ほか：免疫倵活剂胃 癌内投与による胃癌組織内リンパ球漫潤とリンパ 節反応. 臨之研 $61: 2219-2224,1984$

11）山根哲郎, 相良幸彦, 鈴木源一ほか：早期胃癌にお ける術前の内視鏡的腫瘦内 OK-432投与例の検 討. 癌と化㞠 $11: 930-934,1984$ 